\title{
Restoration of degraded sites with suitable tree species in the Mid-hills of Nepal
}

\begin{abstract}
R. K. Jha ${ }^{1 *}$, S. K. Baral ${ }^{1}$, R. Aryal ${ }^{1}$ and H. B. Thapa ${ }^{1}$
Land degradation is a major challenge in Nepal. A lot of degraded land is available within the Community Forests in the Mid-hills which are being aimed to be utilized for ecological restoration as well as supporting livelihoods of the local people. In this context, the study was conducted in the Chautaradanda Community Forest

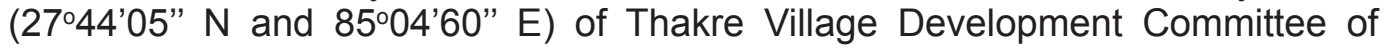
Dhading District in the lower Mid-hills of Central Nepal to test the survival capacity and growth performance of different tree species (native, naturalized as well as exotic) that can be used for the rehabilitation of degraded sites. Firstly, Stylo (Stylosanthes spp.), a leguminous grass, was introduced on a degraded site for enriching nutrients in June 2008. Secondly, six different native, naturalized as well as exotic tree species (Sapindus mukorossi, Prunus cerasoides, Choerospondias axillaris, Melia azedarach, Pinus patula and Robinia pseudoacacia) were planted in a randomized complete block design with 4 blocks (6 species $\times 4$ blocks) in July 2008. The results showed that the growth and survival rate of exotic species, $P$. patula was outstanding; however, the performance of its native and naturalised counterparts $P$. cerasoides, $C$. axillaris and $M$. azedarach was found to be satisfactory. R. pseudoacacia was not found to be a suitable species for rehabilitating degraded sites in the lower Mid-hills of Nepal. Therefore, it would be wise to select the native or naturalized species for the rehabilitation of degraded sites in the Mid-hills, as sometimes the introduction of exotic species may have pessimistic ecological consequences; however, $P$. patula can be used as it has not shown any invasive nature since its introduction (around 1980s) in the Mid-hills of Nepal. Hence, the study shows the possibility of introducing the tree species such as $P$. cerasoides, $M$. azedarach and $C$. axillaris for ecological restoration of degraded sites in the Community Forests in the Mid-hills of Nepal.
\end{abstract}

Key words: Land degradation, growth performance, native species, naturalized and exotic species

$\mathrm{N}$ epal is a mountainous country in the world with about $83 \%$ hills and mountain area (LRMP, 1986). Such hills and mountains are very fragile and susceptible to various land degradation processes. The MoEST (2008) has estimated that over $28 \%$ of the lands in Nepal are in degraded condition. Similarly, according to Bai et al. (2008), Nepal has nearly $39 \%$ of degrading areas from 1981 to 2003. Hence, land degradation is becoming a major challenge for economic and natural ecosystems of Nepal. Many consequences of land degradation such as flooding and sedimentation can be noticed in the Terai, and frequent landslides are noticed in the hills, mostly caused due to loss of forest cover. According to the United Nation Conventions to Combat Desertification (UNCCD), desertification/land degradation is defined as "the reduction or loss of the biological or economic productivity of the terrestrial bio-productive system that comprises soil, vegetation, or other biota and the ecological and hydrological processes that operate within the system". Global Land Assessment of Degradation (GLASOD) has mentioned that land degradation could indeed be a potentially serious threat to food production and rural livelihoods by the year 2020, particularly in more densely populated pockets of rural poverty (Scherr and Yadav, 1996).

Land degradation may occur through different physical, chemical and biological processes directly or indirectly induced by human activities such as deforestation, shifting cultivation, overgrazing, steep slope farming, over use of chemical fertilizers and forest resources (Acharya and Kafle, 2009). About 2,000 million hectares

Department of Forest Research and Survey, Babarmahal, Kathmandu, Nepal

Corresponding author: rajeevk.jha2010@yahoo.com 
of soil, equivalent to $15 \%$ of the Earth's land area (an area larger than the United States and Mexico combined); have been degraded through human activities. The causes of soil degradation include overgrazing (35\%), deforestation $(30 \%)$, agricultural activities (27\%), overexploitation of vegetation (7\%) and industrial activities (1\%) (GACGC, 1994). More than 9 million hectares of forests are being converted into non-forest land, and at least double that amount of forest ecosystem is being fragmented and degraded each year over the world (Uhl and Buschbacher, 1985; Uhl, 1987). According to FRS (1967), the forest and shrub cover in Nepal was around $45.5 \%$ which was reduced to 39.6\% in 1994 (DFRS, 1999; Fig. 1). Converted land is generally agriculturally unproductive, biologically impoverished, and more flammable than the forests (Uhl and Buschbacher, 1985; Uhl, 1987). Human activities are responsible not only for the degradation of land but also important for improvement of land through prevention, rehabilitation and reclamation (MoEST, 2008). In order to address this problem the Government of Nepal (GoN) has initiated handing over of the large areas of forest land including the degraded lands as Community Forests (CFs), particularly in the Mid-hills, to the Community Forest User Groups (CFUGs) for restoration of forests and supply of subsistence forest products to local communities (Kanel and Shrestha, 2001). CF programme is considered as one of the most successful natural resource management programmes in Nepal in terms of restoring degraded land and habitats, conserving biodiversity, increasing supply of forest products, empowering women, poor and the disadvantaged groups, generating rural income, and developing human resources (Gilmour and Fisher, 1991; Acharya, 2003; Springate-Baginski et al., 2003); however, there are lots of degraded lands available in these CFs which need to be utilized for ecological restoration as well as supporting livelihoods of the local people. This will also fulfil one of the major objectives of CF.

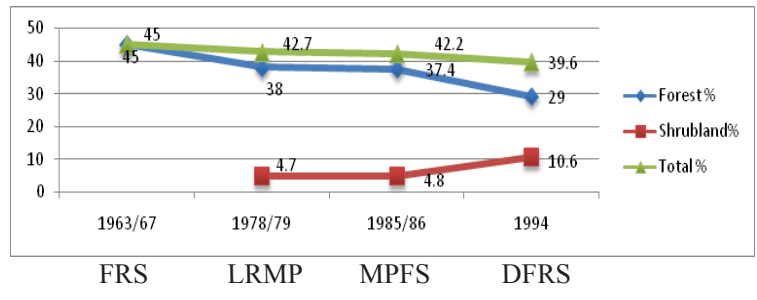

Note: FRS: Forest Resources Survey, LRMP: Land Resource Mapping Project, MPFS: Master Plan for the Forestry Sector, DFRS: Department of Forest Research and Survey

Fig. 1: Change in forest and shrub cover in Nepal
The impressive re-greening of most degraded sites seems unlikely to be reversed, provided that grazing; forest fire bans are maintained (http:// www.ifad.org/events/reducingpoverty/nepal.html accessed in October 2013). However, it takes time to come up with desired species, and there is growing interest in establishing plantations of native species in recent years (Gonzalez and Fisher, 1994; Montagnini, 2000; Piotto et al., 2002). Therefore, this study aims to test the survival capacity and the growth performance of different tree species (native, naturalized and exotic) for the rehabilitation of degraded lands.

\section{Materials and methods}

\section{Study area}

The Chautaradanda CF $\left(27^{\circ} 44^{\prime} 05^{\prime \prime} \mathrm{N}\right.$ and $85^{\circ} 04^{\prime} 60^{\prime \prime}$ E) located at Thakre Village Development Committee (VDC) Ward No. 3 of Dhading District in the lower Mid-hills of Central Nepal was selected as a restoration site (Fig. 2). The restoration site is located at an altitude of $1000 \mathrm{~m}$ with 30 to $35 \%$ slope facing southern aspect. The climate is sub-tropical with mean monthly temperatures ranging from 13 to $27^{\circ} \mathrm{C}$, mean monthly rainfall from 7 to $341 \mathrm{~mm}$, and average annual rainfall of nearly $1,700 \mathrm{~mm}$. More than $80 \%$ of the total rainfall occurs from June to September, as recorded at the nearest meteorological station of Dhunibeshi (Baul et al., 2013). There are three distinct seasons: rainy (wet); winter; and hot or humid summer (Tiwari, 2008). The drainage condition is good but with excessive run-off, resulting in deficiency of soil moisture. The soil is, moreover, shallow and stony, and at some places, eroded leaving only the bare rocks. Initially, the study area was barren; however, the CFUG had tried to afforest that area in July, 2006 by planting nursery-grown seedlings of various species such as: Shorea robusta, Alnus nepalensis, Choerospondias axillaris and Pinus roxburghii but their growth was not satisfactory except $A$. nepalensis in moist sites. But, now $S$. robusta is appearing sporadically naturally in that area that may be attributed to the enriched soil condition and easy availability of its seed from the surrounding natural $S$. robusta forest.

\section{Soil characteristic of the study site}

The soil condition before the commencement of the study was analysed by taking representative composite soil samples from three depths 


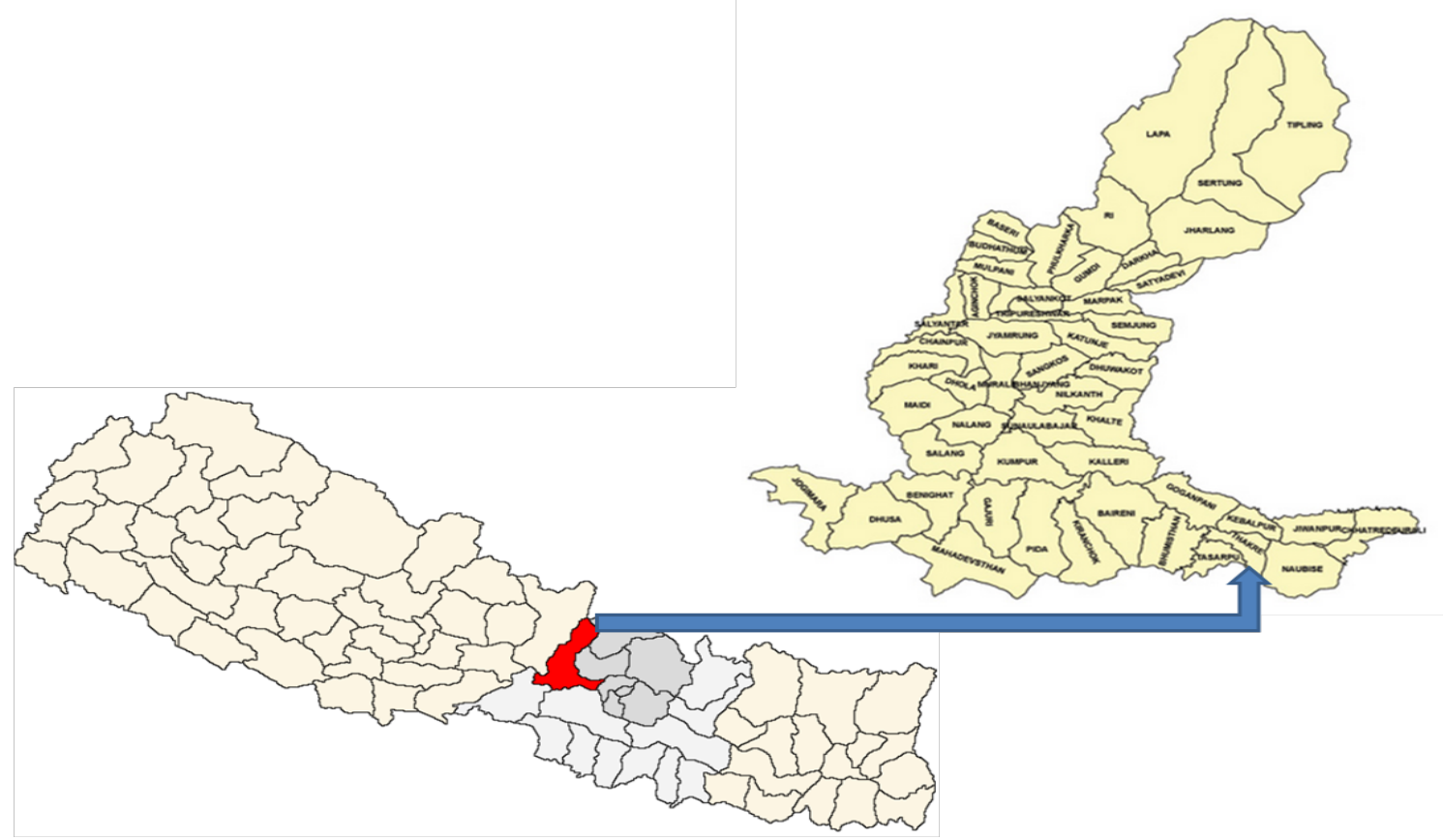

Fig. 2: Map of the study area

(0-15 cm, $15-30 \mathrm{~cm}$ and $30-50 \mathrm{~cm})$.

\section{Efforts made for soil enrichment}

After land preparation, the seeds of Stylo (Stylosanthes spp.), a leguminous grass, were sown just one month before planting seedlings of the tree species; and $4 \mathrm{~kg}$ of farmyard manure was applied around each seedling every year during April-May for three years so as to enrich the soil. A trench was constructed around each pit in order to conserve moisture because of the dry soil condition.

\section{Species selection}

The species for this study were selected on the basis of discussion with the CF members and experts. In addition, other criteria used were user groups' preference, site quality, market possibilities, economical or financial viability, and identified nursery and cultivation techniques, availability of seedlings and short rotation or quick harvest.

The selected species were Prunus cerasoides (Paiyu), Choerospondias axillaris (Lapsi), Sapindus mukorossi (Ritha), Melia azedarach (Bakaino), Pinus patula (Pate Sallo) and Robinia pseudoacacia.

About $30 \mathrm{~cm}$ tall seedlings, grown in $4 " \times 7$ " polythene pots in the Chalnakhel Nursery of the Department of Forest Research and Survey (DFRS), were planted at a spacing of $2.5 \mathrm{~m}$ by $2.5 \mathrm{~m}$ in July, 2008.

\section{Experimental design}

Randomized complete block design with four replicates (blocks) and six treatments (species) were applied. The blocks were constructed from east to west along the contour and divided into six plots. Location of the plot for each species within the array was determined randomly for every block, and then the seedlings were planted. Each species was represented by one plot per block, and 25 individuals per plot for a total of 100 trees per species in the experiment.

\section{Data collection and analysis}

The soil samples were brought to the soil labouratory of the DFRS for analysis to get idea about soil features such as texture, $\mathrm{pH}$, nitrogen $(\mathrm{N})$, phosphorous $(\mathrm{P})$, potassium $(\mathrm{K})$, cation exchange capacity (CEC) and organic matter content.

Survived seedlings were counted, and their heights were measured using a stick and simple measuring tape, and recorded in the tally-form each year during February-March. Simple statistical technique (mean, standard deviation) were used for data analysis in SPSS 16. Two-way analysis of variance (ANOVA) technique at 5\% 
level was applied to know whether height growth and survival were significant.

However, as the data for survival showed more than 20\% variation, an angular (arcsine) transformation technique was used before employing ANOVA test. Further, post-hoc test was applied using Tukey HSD test for multiple comparisons in survival of species; however, due to only one value for a species ( $R$. pseudoacacia), this technique was not applied for height of the species.

\section{Results and discussion}

\section{Soil features}

The results of soil analysis showed that the soil type was sandy loam to loam with 6.35 average $\mathrm{pH}$ values. Other soil features such as $\mathrm{N}, \mathrm{P}, \mathrm{K}$, CEC and organic matter content were $0.69 \mathrm{mg} / \mathrm{g}$, $0.31 \mu \mathrm{g} / \mathrm{g}, 20.58 \mu \mathrm{g} / \mathrm{g}, 2.03 \mathrm{meq} / 100 \mathrm{~g}$ and $1.6 \%$ respectively (Table 1).

The soil features of this site were compared with the findings of Baral (2008) from a well stocked $\mathrm{CF}$ in Kavreplanchowk District. The comparison showed that the availability of both nitrogen and potassium at this site was about one third of those available in the well stocked CFs. On the contrary, the availability of phosphorous was found to be nearly three times more than that available in the well stocked CFs, indicating the poor condition of the site. Common soil problems in the deforested tropics include aluminium toxicity, low $\mathrm{pH}$ and phosphorous fixation (Fisher, 1995 cited in Carpenter et al., 2004). Excess phosphorus may cause micronutrient deficiencies, especially iron or zinc (Available online at: http://www.cartage. org.lb/en/themes/Sciences/BotanicalSciences/ PlantHormones/EssentialPlant/EssentialPlant. html accessed in October 2013).

\section{Growth performance of Stylosanthes spp.}

The growth performance of Stylosanthes spp. was found to be satisfactory in the first year; however, it showed poor results afterwards, which could be due to shade provided by the adjoining grown tree species.

\section{Survival}

The survival per cent of $P$. patula, $P$. cerasoides, S. mukorossi, M. azedarach, C. axillaris and $R$. pseudoacacia after three years were found to be $82,77,70,64,52$ and $1 \%$ respectively (Fig. 3 ). The exotic species are at extremes (highly survived and least survived i.e. almost failed). Among the native species, $P$. cerasoides showed the best result followed by the native species, $S$. mukorossi, and the naturalized species, $M$. azedarach (Fig. 3).

After angular (arcsines) transformation, ANOVA test indicated that there was significant difference $(p \leq 0.05)$ in survival of selected species (Table $2)$. The significant difference in survival was found between $P$. patula and $C$. axillaris; and $R$. pseudoacacia with all species (Annex 1).

A lot of plantations of $P$. patula have been established since 1980s in the Mid-hills of Nepal. In most of the sites; it shows over $80 \%$ survival (Jackson, 1994). On an average, the survival of $P$. patula at the age of three years was recorded

Table 1: Soil characteristics

\begin{tabular}{lrrrr}
\hline \multicolumn{1}{c}{ Parameters } & Min. & Max. & Mean & $\begin{array}{r}\text { Std. error of } \\
\text { mean }\end{array}$ \\
\hline $\mathrm{pH}(1: 1)$ & 5.70 & 7.70 & 6.35 & 0.46 \\
Available Nitrogen $(\mathrm{mg} / \mathrm{g})$ & 0.52 & 1.08 & $0.69\left(1.825^{*}\right)$ & 0.13 \\
Available Phosphorous $(\mu \mathrm{g} / \mathrm{g})$ & $<0.05$ & 0.68 & $0.31\left(0.095^{*}\right)$ & 0.16 \\
Available Potassium $(\mu \mathrm{g} / \mathrm{g})$ & 11.14 & 39.50 & $20.58\left(64.20^{*}\right)$ & 6.51 \\
Organic Matter $(\%)$ & 1.13 & 2.33 & 1.60 & 0.29 \\
$\begin{array}{l}\text { Cation Exchange Capacity } \\
\text { (meq/100g) }\end{array}$ & 1.93 & 2.15 & 2.03 & 0.05 \\
Texture & Sandy Loam to Loam & & \\
\hline
\end{tabular}

*Source: Baral (2008) 
as $73 \%$ in $1981-1982$, and the same in 1983 at Tistung (1,800-2,000), Makwanpur District (CFDP, 1984); 87\% at Lopre (2,300 m), Parbat District of Nepal (Paudel et al., 1996). Similarly, a study on poor site at an altitude of $1,100 \mathrm{~m}$ in Syangja District shows the survival rate of $83 \%$ at an age of 4.7 years (Neil, 1989). Likewise, other survival results from the trial plots of Forest Research Division are $58 \%$ at the age of four years in Lauke $(1,450 \mathrm{~m}) ; 81 \%$ and $100 \%$ at the age of 6.8 and 2.4 years respectively in Tistung $(2,000 \mathrm{~m})$, Makwanpur District; and 69\% and $85 \%$ at the age of 2.7 and 1.4 years respectively in Kharidhunga, Dolkha (Neil, 1989). According to Joshi and Wyatt-Smith (1982), the survival rate of $P$. patula in the plots established by the Nepal-Australia Forestry Project in the late 1970s is $92 \%$ after seven years at the Lower Nagarkot $(1,700 \mathrm{~m})$, and $76 \%$ at the Upper Nagarkot $(2,000 \mathrm{~m})$. Also, the survival results of this species from Tistung $(1,900 \mathrm{~m})$ are $97 \%$ and $81 \%$ after 4.5 and 6.8 years respectively (Jackson, 1994). The result of this study is also in line with all those studies. However, P. patula has been listed as Category 2 Invader in South Africa (invaders with certain qualities, e.g. commercial use or for woodlots, animal fodder, soil stabilisation, etc) and are allowed in certain areas under controlled conditions as they have significantly reduced water availability and also have a very negative impact on plants in the fynbos, an area of global biodiversity significance (BioNET-EAFRINET: Key and Fact Sheets). Nevertheless, it has not yet been reported such nature of this species in Nepal, despite, a study on "Regeneration establishment of native broadleaves in pine plantations in Nepal" reveals the positive results in the regeneration establishment of natural broadleaved species (Gautam et al., 1996). However, the plantation of this species needs long-term specific results from their trials before going for large-scale plantations.

In a plantation done by Community Forestry Development Project (CFDP) in 1983, the survival rate of $R$. pseudoacacia was found to be less than 10\% (CFDP, 1984). Jackson (1994) suggests for research on this species in smallscale trial plots for three to four years before attempting for large scale plantations. Similarly, a study from St. Neots and Aldewood, Britain shows very poor survival rate even on better quality sites (Willoughby et al., 2007). On the contrary, the survival rate of this species is
$83 \%$ after second growing season on a site with high $\mathrm{pH}$, high nutrient content, high electrical conductivity and high sodium concentrations (http://www.ibaf.cnr.it/phyto/schedel ROBINIA\%20PSEUDACACIA\%20-\%20Zn,\%20 $C d, \% 20 P b, \% 20 N a . p d f$ assessed in November 2013) and is considered as an ideal tree for erosion control and soil stabilization, and an excellent farm forestry tree in Pakistan (Sheikh, 1993).

The CFDP reports the survival rate of $S$. mukorossi is only $27 \%$ in the plantation sites and $43 \%$ in the farmers' land for the years 1981 and 1982 (Campbell and Bhattarai, 1983). A bareroot planting of this species, in Darchula District, shows 30 to $50 \%$ survival only (Wilson, 1988). The survival per cent, however, in this study is very much promising that may be because of increasing soil nitrogen availability due to application of farmyard manure and Stylosenthes plantation.

The survival per cent of $P$. cerasoides is $92 \%$ at the age of seven years at the Upper Nagarkot, Bhaktapur District at an altitude of 2,000 $\mathrm{m}$ (Joshi and Wyatt-Smith, 1982); and $86 \%$ at an altitude of $1800 \mathrm{~m}$ near Lumle in Parbat District (Shrestha and Gautam, 1991). According to Shakya (1991) the survival of $P$. cerasoides is $100 \%$ at Kadambas $(1,440 \mathrm{~m})$, Sindhupalchowk District, $89 \%$ at Naldung $(1,600 \mathrm{~m})$ and $97 \%$ at Nagarkot $(1,700 \mathrm{~m})$, Bhaktapur District after 18 months, $78 \%$ at Kadambas (1,440 m) after 30 months. In general, the survival rate of this species in Nepal is over $80 \%$ at the age of two years (Jackson, 1994). A very contradictory result is found on a degraded Watershed area $\left(18^{\circ} 52^{\prime} \mathrm{N}, 94^{\circ} 51^{\prime} \mathrm{E}\right.$, 1,207-1,310 $\mathrm{m}$ above mean sea level) in Doi Suthep-Pui National Park of Thailand, where the survival rate of $P$. cerasoides plantation with four fertiliser (NPK 15-15-15) treatments over one growing season are recorded as $85.7 \%, 61.5 \%$, $80.0 \%$ and $62.5 \%$ respectively with an overall average of $72.4 \%$ (Elliott et al. non-dated).

The survival rate of 28 months old $C$. axillaris is $80 \%$ at Kadambas $(1,500 \mathrm{~m})$, Sindhupalchowk District (Jackson, 1994). Shakya (1991) states that the survival rate of C. axillaris is $83 \%$ after 18 months and $71 \%$ after 30 months at Kadambas $(1,440 \mathrm{~m})$ and $78 \%$ after 18 months at Nagarkot $(1,700 \mathrm{~m})$. However, these results contradict with the findings of this research as it showed the 
survival rate of $C$. axillaris as $52 \%$ after three years. This contradictory result may be attributed to poor site condition.

\section{Height growth}

The growth of M. azedarach is influenced by soil depth and fertility, and it is capable of achieving very rapid growth on deep, well-drained and reasonably fertile soil (Jackson, 1994). A study from northwest India, on a calcareous soil in a semi-arid part (annual rainfall about $350 \mathrm{~mm}$ ), shows the survival rate of $M$. azedarach in 3 years as $100 \%$ (Tomar et al., 2003). In Nepal, the survival rate of this species is $90 \%$ in 13 months from taungya plantation in Dang, and 55\% in the 1981- and 1982- CF plantations and 37\% in the 1983- CF plantations (Jackson, 1994). However, the findings of this research, though from degraded site, shows the better result than the 1981, 1982 and 1983 results of the Community Forestry Development Project. These results indicate that if care is applied to $M$. azedarach plantation, it would be a better option to rehabilitate degraded sites in the lower Mid-hills; however, a detailed study needs to be conducted in other areas so as to know the real causes of these contradictions.
The heights of $P$. patula, $P$. cerasoides, $S$. mukorossi, $M$. azedarach, $C$. axillaris and $R$. pseudoacacia at the age of three years were found to be $2.63 \mathrm{~m}, 1.59 \mathrm{~m}, 0.62 \mathrm{~m}, 1.88 \mathrm{~m}, 1.43 \mathrm{~m}$ and $0.51 \mathrm{~m}$ respectively (Fig. 4).

(ANOVA) test indicated that there was significant difference $(\mathrm{p} \leq 0.05)$ in height growth of the tested species (Table 3 ).

On a good site, P. patula trees may reach $2 \mathrm{~m}$ in height after two years (http://www.forestrynepal. org/resources/trees/pinus-patula accessed in November 2013). A study from Tistung $(1,800$ 2,000 m), Makawanpur, District on infertile sites shows the height gain of $P$. patula as 3.4 $\mathrm{m}$ at the age of three years (Jackson, 1994). Similarly, seven-year-old trees of this species at Lower (1,760 m) and Upper (2,000 m) Nagarkot, Bhaktapur District have attained the height of $10.6 \mathrm{~m}$ and $9 \mathrm{~m}$, respectively (Joshi and WyattSmith, 1982). Likewise, the mean height growth results from Forest Research Division trials are $3.6 \mathrm{~m}$ at the age of 4.7 years in Syangja District $(1,100 \mathrm{~m}) ; 3.6 \mathrm{~m}$ in 4 years at Lauke $(1,450$ $\mathrm{m})$, Nuwakot District; $9.8 \mathrm{~m}$ and $2.3 \mathrm{~m}$ at the age of 6.8 and 2.4 years respectively at Tistung $(2,000 \mathrm{~m})$, Makawanpur District; and $1.0 \mathrm{~m}$ and

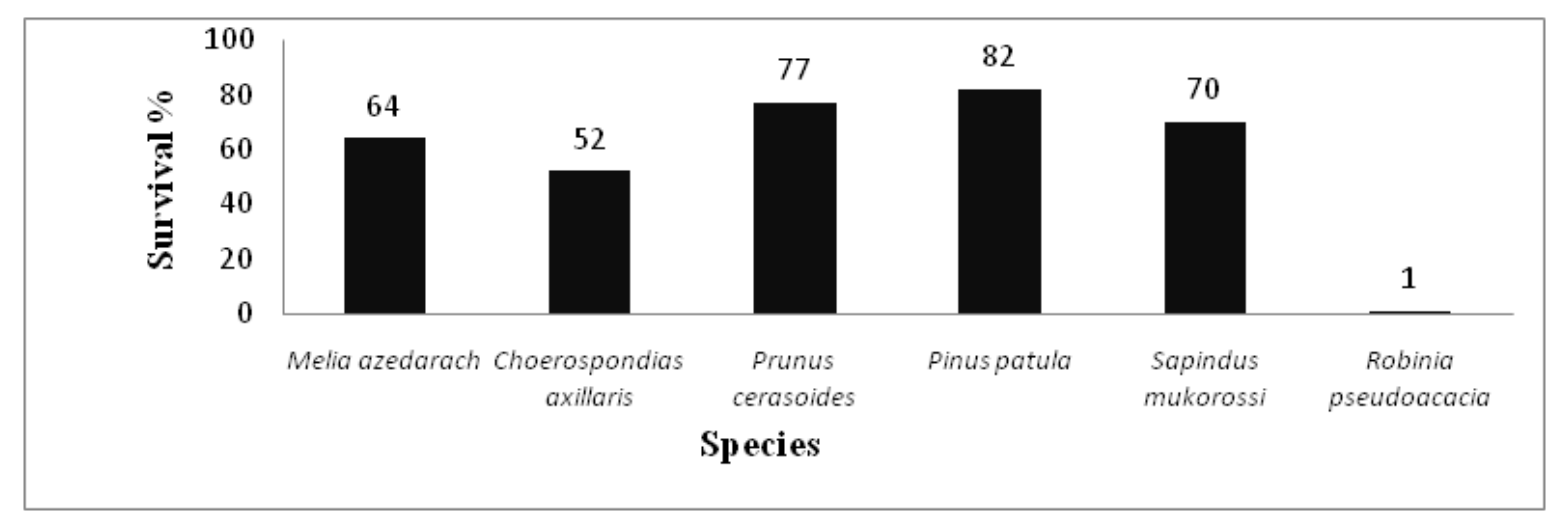

Fig. 3: Survival per cent of different tree species in three years

Table 2: ANOVA table for survival of the tested species

\begin{tabular}{lrrrrr}
\hline \multicolumn{1}{c}{ Source } & $\begin{array}{r}\text { Degree of } \\
\text { freedom }\end{array}$ & Sum of Squares & Mean Square & F & Sig. \\
\hline Species & 5 & 1863.188 & 372.638 & 57.025 & 0.000 \\
Block & 3 & 25.738 & 8.579 & 1.313 & 0.307 \\
Error & 15 & 98.019 & 6.535 & & \\
\hline Total & $\mathbf{2 3}$ & $\mathbf{1 9 8 6 . 9 4 6}$ & & & \\
\hline
\end{tabular}

$\mathrm{R}^{2}=0.951\left(\right.$ Adjusted $\left.\mathrm{R}^{2}=0.924\right)$ 
$0.7 \mathrm{~m}$ at the age of 2.7 and 1.4 years respectively at Kharidhunga (2,700 m), Dolkha District (Neil, 1989). A study from India shows the average height of P. patula as $11.78 \mathrm{~m}$ in 12 years at Devidhura, Uttarakhand and $8.24 \mathrm{~m}$ in 8 years at Lohaghat Reserve, Uttaranchal (Chaturvedi and Dwibedi, 1982). The height growth of this species in this study was found to be similar to those from other studies.

$R$. pseudoacacia has shown higher growth rate of $53 \mathrm{~cm}$ after second growing season on a site with high $\mathrm{pH}$, high nutrient content, high electrical conductivity and high sodium concentrations (http://www.ibaf.cnr.it/phyto/schede/ROBINIA $\% 20 P S E U D A C A C I A \% 20-\% 20 \mathrm{Zn}, \% 20 C d, \% 20$ $P b, \% 20 N a . p d f$ accessed in November 2013) which is comparable to the findings of this research (51 cm after three years), even though it is from poor site. It can grow up to about $25 \mathrm{~m}$ at maturity. In general, the growth performance of this species is poor in Nepal. Therefore, Jackson (1994) has envisaged that it needs appropriate amount of winter rainfall or snowfall to grow well, as it has shown better performance in the northwest Himalaya of Kashmir and Himachal Pradesh, India.

S. mukorossi has proved successful in the afforestation of eroded hill slopes at elevations below $900 \mathrm{~m}$ in the Western Himalayas in India (http://www.worldagroforestrycentre.org/ SEA/Products/AFDbases/AF/asp/SpeciesInfo. asp? SpID $=1767$ accessed in November 2013). In Pakistan, this species showed the height and diameter growth of $9 \mathrm{~m}$ and $10 \mathrm{~cm}$ in five years respectively (Sheikh, 1993). The growth rate of this species was found to be poorer in this study as compared to the one in plantation. It may be due to dry and poor site condition as it requires moist site (Sheikh, 1993) and it does not grow on very poor and rocky sites.

P. cerasoides has attained the height of over $2 \mathrm{~m}$ in seven years at the Upper Nagarkot $(2,000 \mathrm{~m})$, Bhaktapur District (Joshi and WyattSmith, 1982) and it gained the mean height of $1.3 \mathrm{~m}$ at another site with the same age at an altitude of 1,800 m near Lumle in Parbat District
(Shrestha and Gautam, 1991). In general, the mean height of this species in Nepal is about 1 $\mathrm{m}$ in two years (Jackson, 1994). The best height attained from unfertilized plantations in open area is $1.75 \mathrm{~m}$ at 2.4 years at Banduk $(1,450 \mathrm{~m})$, Myagdi District (Joshi, 1985); $1.6 \mathrm{~m}$ at 2.2 years on a poor site with northern aspect at Nisikot (1,400 m), Dhading District (Rimal, 1992), and $2.8 \mathrm{~m}$ at four years at $1,800 \mathrm{~m}$ in Parbat District (Shrestha and Gautam, 1991).

According to Jackson (1994), the growth of C. axillaris is rapid only on good fertile soil, averaging about $1 \mathrm{~m}$ in height per year; but in general, its growth is much slower. One of the best results in trials is from Kadambas $(1,500 \mathrm{~m})$, Sindhupalchowk District where 28 month-old trees have attained a mean height of $101 \mathrm{~cm}$. Jackson (1994) reported the average height of this species as about $60 \mathrm{~cm}$ after two years, and $90 \mathrm{~cm}$ after three years. However, the finding of this study contradicts with the others as it shows the height growth of C. axillaris as 1.43 $\mathrm{m}$ in three years. This contradictory result may be due to application of manure. Nevertheless, a detailed study needs to be conducted to know the real causes.

The growth of M. azedarach is influenced by soil depth and fertility, and it is capable of achieving very rapid growth on deep, well-drained and reasonably fertile soil (Jackson, 1994). In Thailand, on a deep red loam, at 1,000 m, and with about $1,500 \mathrm{~mm}$ annual rainfall, trees have attained $3 \mathrm{~m}$ height within a year. Similarly, the height growth of this species recorded is $4.5 \mathrm{~m}$ in 13 months under taungya plantation in Dang District, Nepal (Jackson, 1994). But, a study on a calcareous soil in a semi-arid part (annual rainfall about $350 \mathrm{~mm}$ ) in northwest India shows the height growth of $M$. azedarach in three years as $3.86 \mathrm{~m}$ (Tomar et al., 2003). The findings of this current research showed slow growth rate of this species in degraded sites in spite of manuring. Therefore, a detail study needs to be conducted in other areas so as to know the real causes of these contradictions. 


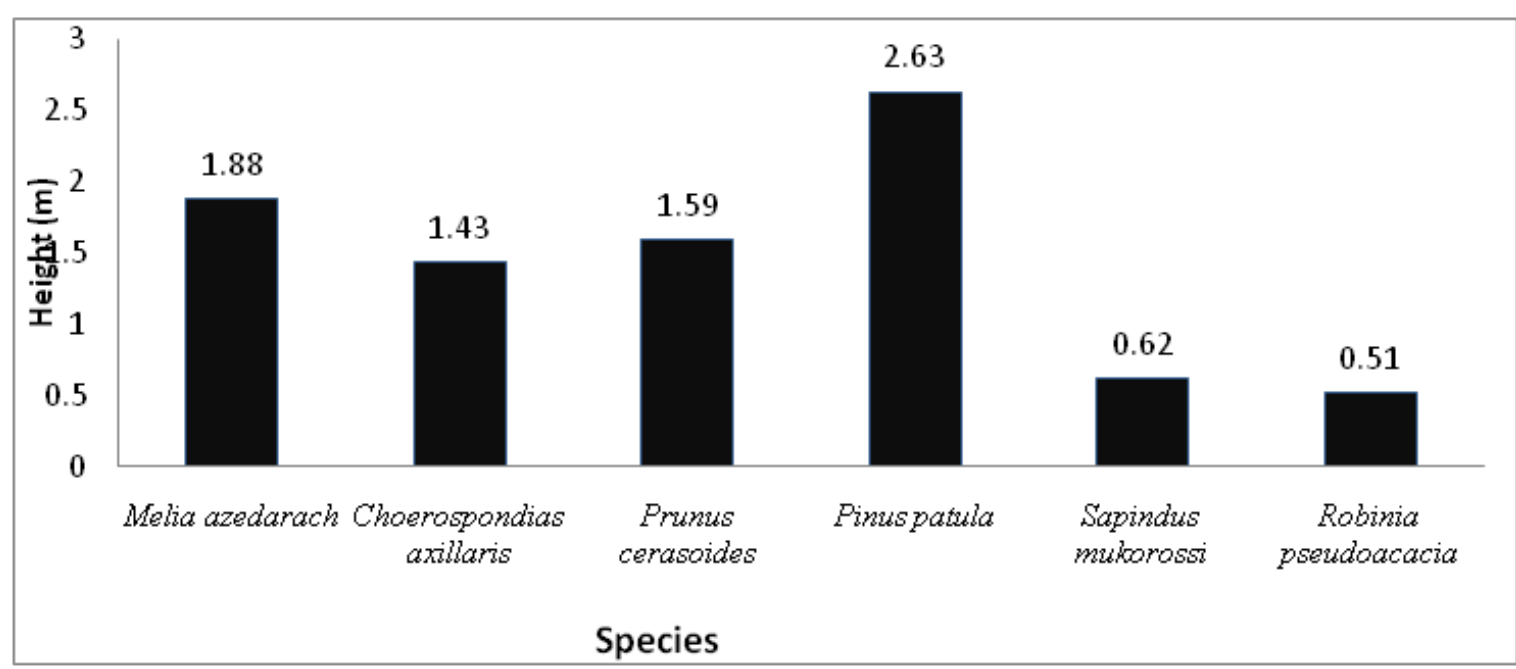

Fig. 4: Height growth of different species in three years

Table 3: ANOVA table for height of the tested species

\begin{tabular}{lrrrrr}
\hline \multicolumn{1}{c}{ Source } & $\begin{array}{r}\text { Degree of } \\
\text { freedom }\end{array}$ & Sum of Squares & Mean Square & F & Sig. \\
\hline Species & 5 & 156.528 & 31.306 & 68.956 & 0.000 \\
Block & 3 & 4.367 & 1.456 & 3.2073 & 0.023 \\
Error & 341 & 154.811 & 0.454 & & \\
\hline Total & $\mathbf{3 4 9}$ & $\mathbf{3 1 7 . 1 4 9}$ & & & \\
\hline
\end{tabular}

$\mathrm{R}^{2}=0.512\left(\right.$ Adjusted $\left.\mathrm{R}^{2}=0.500\right)$

\section{Conclusion}

This study showed that the native species can grow very well on degraded sites. Though, $P$. patula, the exotic species, showed the outstanding results, we have to be cautious when recommending it as it is an exotic species and may have a chance to be invasive like in Africa. Native and naturalised species such as $P$. cerasoides, $C$. axillaris and $M$. azedarach were found to have performed relatively better. Another exotic species $R$. pseudoacacia was not successful in this study, and also not in other parts of Nepal. Therefore, it is recommended to prefer the native or naturalised species for the rehabilitation of degraded sites in the Mid-hills. It would be wise to conduct a preliminary study before planting these species in other parts of the Mid-hills for the rehabilitation of degraded land.

\section{Acknowledgements}

We would like to thank the members of the Executive Committee of Chautaradanda Community Forest User Group, Thakre VDC, Dhading District for providing the site for establishment of trial plot and mutual cooperation for establishing, managing and protecting the trial plot. Our thanks also go to District Forest Office, Dhading for their coordination.

\section{References}

Acharya, A. K. and Kafle, N. 2009. Land degradation issues in Nepal and its management through agroforestry. The Journal of Agriculture and Environment 10: $115-123$.

Acharya, K. P. 2003. "Conserving Biodiversity and Improving Livelihoods: The Case of Community Forestry in Nepal" paper presented in International Conference on Rural Livelihood, Forests and Biodiversity, Bonn, Germany.

Bai, Z. G., Dent, D. L., Olsson, L. and Schaepman, M. E. 2008. Global Assessment of Land Degradation and Improvement. 1. Identification by Remote Sensing. Report 2008/01, ISRIC - World Soil Information, Wageningen, Netherlands. 
Baral, S. K. 2008. Impacts of Forest Management on Selected Ecosystem Properties. Master Thesis, BOKU, Vienna, Austria.

Baul, T. K., Ullah, K. M. A., Tiwari, K. R. and McDonald, M. A. 2013. People's local knowledge of climate change in the Middle-hills of Nepal. Indian Journal of Traditional Knowledge 12 (4): 585-595. (Available online at: http://nopr.niscair. res.in/bitstream/123456789/22177/1/ IJTK\%2012(4)\%20585-595.pdf accessed in October, 2013 ).

BioNET-EAFRINET: Key and Fact Sheets. Available online at: http://keys.lucidcentral. org/keys/v3/eafrinet/weeds/key/weeds/ Media/Html/Pinus_patula_\%28Patula_ Pine\%29.htm accessed in October, 2013.

Campbell, J. G. and Bhattarai, T. N. 1983. Community Forestry private planting survey results. Nepal Forestry Technical Information Bulletin 8: 20-30.

Carpenter, F. L., Nichols, J. D. and Sandi, E. 2004. Early growth of native and exotic trees planted on degraded tropical pasture. Forest Ecology and Management 196: 367-378. (Available online at: www.sciencedirect.com accessed in October, 2013).

CFDP. 1984. Annual Progress Report for 198384 (2040-41), by Monitoring and Evaluation Unit. Miscellaneous Document. 23. Community Forestry Development Project, HMG/UNDP/FAO, Kathmandu, Nepal.

Chaturvedi, A. N. and Dwibedi, B. N. 1982. Exotic pine trials in Uttar Pradesh. The Indian Forester 108 (2): 133-134.

DFRS. 1999. Forest Resources of Nepal. Department of Forest Research and Survey. Publication No 74, Kathmandu, Nepal.

Elliott, S., Navakitbumrung, P., Zangkum, S., Kuarak, C., Kerby, J., Blakesley, D. and Anusarnsunthorn, V. non-dated. Performance of six native tree species, planted to restore degraded forest land in Northern Thailand and their response to fertilizer. Available online at www.forru.org/PDF.../p45\%20Elliot $\% 20$ performance\%20of\%20si.pdf accessed in October, 2013.
Fisher, R. F. 1995. Amelioration of degraded rain forest soils by plantations of native trees. Soil Science Society of America Journal 59: 544-549.

FRS. 1967. Forest Statistics of Terai and Adjoining Regions. Forest Resources Survey, Publication No. 4, Department of Forests, Kathmandu, Nepal.

GACGC. 1994. World in Transition: The Threat to Soils. Annual Report. German Advisory Council on Global Change. Bonn, Economica Verlag $\mathrm{GmbH}$ cited in Global Environment Outlook 3: Past, Present and Future Perspectives. United Nations Environment Programme. Earthscan Publications Ltd. London. Sterling, VA. 2002. Available online at: http://www.centrogeo. org.mx/unep/docu-mentos/Geo-3/GEO_3.pdf assessed in November 2013.

Gautam, K. H., Skovsgaard, J. P. and Johannsen V. K. 1996. Regeneration establishment of native broadleaves in pine plantations in Nepal. In Modelling Regeneration Success and Early Growth of Forest Stands Danish Forest Landscape Research Institute, Horsholm, Denmark, 41-47.

Gilmour, D. A. and Fisher, R. J. 1991. Villagers, Forest and Foresters: the Philosophy, Process and Practice of Community Forestry in Nepal. Kathmandu, Nepal.

Gonzalez, E. J. and Fisher, R. F. 1994. Growth of native forest species planted on abandoned pasture land in Costa Rica. Forest Ecology and Management 70: 159-167.

Jackson, J. K. 1994. Manual of Afforestation in Nepal. 2nd edition. Forest Research and Survey Centre, Kathmandu, Nepal.

Joshi, M. R. and Wyatt-Smith, J. 1982. Some preliminary indications from research for forest management guidance in the hills of Central Nepal. Nepal Forestry Technical Information Bulletin 7: 7-22.

Joshi, R. B. 1985. An Interim Report on Tree Species Trials in RCUP Area. Unpublished Report. Forest Resource and Survey Office, Kathmandu, Nepal. 
Kanel, K. and Shreshtha, K. 2001. Tropical secondary forests in Nepal and their importance to local people. Journal of Tropical Forest Science 13 (4): 691-704.

LRMP. 1986. Summary Report. HMGN/ Government of Canada. Kenting Earth Sciences Limited: Kathmandu, Nepal.

MoEST. 2008. State of the Environment (Agriculture, Forest and Biodiversity). Ministry of Science and Technology, Singh Durbar, Kathmandu.

Montagnini, F. 2000. Accumulation in aboveground biomass and soil storage of mineral nutrients in pure and mixed plantations in a humid tropical lowland. Forest Ecology and Management 134 (1-3): 257-270.

Neil, P. E. 1989. Research experience with pines in Nepal. Banko Janakari 2 (2): 103-107.

Paudel, K. C., Amatya, S. M. and Harrison, A. 1996. Provenance Trial of Pinus maximinoi and Comparison with Pinus wallichiana and Pinus patula. Working Paper - Lumle Regional Agricultural Research Centre, Lumle, Nepal.

Piotto, D., Montagnini, F., Kanninen, M., Ugalde, L. and Viquez, E. 2002. Comportamiento de las especies y preferencias de los productores: planatciones forestales en Costa Rica y Nicaragua. Revista Forestal Centroamericana 38: 59-66.

Rimal, S. 1992. Preliminary research note from Nepal Coppice Reforestation Program, Dhading. Banko Janakari 3 (2): 40-41.

Scherr, J. S. and Yadav, S. 1996. Land Degradation in the Developing World: Implications for Food, Agriculture, and the Environment to 2020. Food, Agriculture, and the Environment Discussion Paper 14. International Food Policy Research Institute 1200 Seventeenth Street, N. W. Washington, D. C., U.S.A.

Shakya, R. 1991. Preliminary results of broadleaved species trials in the Middle Hills. Banko Janakari 3 (1): 9-12.

Sheikh, M. I. 1993. Trees of Pakistan (Available online at: http://pdf.usaid.gov/pdf_docs/
PNABW250.pdf accessed in October, 2013)

Shrestha, R. K. and Gautam, N. 1991. Evaluation of LRARC Community Planting in Parbat District. Technical Paper No. 291, Lumle Agriculture cultural Centre, Lumle, Nepal.

Springate-Baginski, O., Dev, O. P., Yadav, N. P. and Sousan, J. 2003. Community forest management in the middle hills of Nepal: the changing context. Journal of Forest and Livelihood 3: 5-20.

Tiwari, K. R. 2008. Land Management and Soil Conservation Options for Sustainable Agricultural Production in a Middle Mountain Watershed of Central Nepal. M.Sc. Thesis, Norwegian University of Life Sciences, Ås, Norway.

Tomar, O. S., Minhas, P. S., Sharma, V. K., Singh, Y. P. and Gupta, R. K. 2003. Performance of 31 tree species and soil conditions in a plantation established with saline irrigation. Forest Ecology and Management 177: 333-346.

Uhl, C. 1987. Factors controlling succession following slash and burn agriculture in Amazonia. Journal of Ecology 75: 377-407.

Uhl, C. and Buschbacher, R. 1985. A disturbing synergism between cattle ranch burning practices and selective tree harvesting in the eastern Amazon. Biotropica 17: 265-268.

Willoughby, I., Victoria Stokes, V., Poole, J., White, J. E. J. and Hodge, S. J. 2007. The potential of 44 native and non-native tree species for woodland creation on a range of contrasting sites in lowland Britain. Forestry Oxford Journals 80 (5): 531-553. Available online at: forestryforestry.oxfordjournals.org accessed in October, 2013.

Wilson, A. 1988. Community Forestry Development in Darchula District. Miscellaneous Document. 49.

\section{Websites:}

http://www.cartage.org.lb/en/themes/ Sciences/BotanicalSciences/PlantHormones/ EssentialPlant/EssentialPlant.html accessed in October 2013 
http://www.forestrynepal.org/resources/trees/ pinus-patula accessed in November, 2013.

http://www.ifad.org/events/reducingpoverty/ nepal.htm accessed in October, 2013. http://www.ibaf.cnr.it/phyto/schede/ ROBINIA\%20PSEUDACACIA\%20-\%20Zn,\%20 $C d, \% 20 P b, \% 20 N a . p d f$ accessed in November, 2013.

http://www.worldagroforestrycentre.org/SEA/ Products/AFDbases/AF/asp/SpeciesInfo. asp? SpID=1767 accessed in November, 2013.

Annex 1

Multiple comparisons for survival using Tukey's HSD

\begin{tabular}{lcccccc}
\hline & $P$. & $S$. & $P$. & $C$. & $M$. & $R$. \\
& cerasoides & mukorossi & patula & axillaris & azedarach & pseudoacacia \\
\hline P. cerasoides & - & $\mathrm{ns}$ & $\mathrm{ns}$ & $\mathrm{ns}$ & $\mathrm{ns}$ & $*$ \\
S. mukorossi & $\mathrm{ns}$ & - & $\mathrm{ns}$ & $\mathrm{ns}$ & $\mathrm{ns}$ & $*$ \\
P. patula & $\mathrm{ns}$ & $\mathrm{ns}$ & - & $*$ & $\mathrm{~ns}$ & $*$ \\
C. axillaris & $\mathrm{ns}$ & $\mathrm{ns}$ & $*$ & - & $\mathrm{ns}$ & $*$ \\
M. azedarach & $\mathrm{ns}$ & $\mathrm{ns}$ & $\mathrm{ns}$ & $\mathrm{ns}$ & - & $*$ \\
R. pseudoacacia & $*$ & $*$ & $*$ & $*$ & $*$ & - \\
\hline
\end{tabular}

* The mean difference is significant at 0.05 level; ns - not significant 